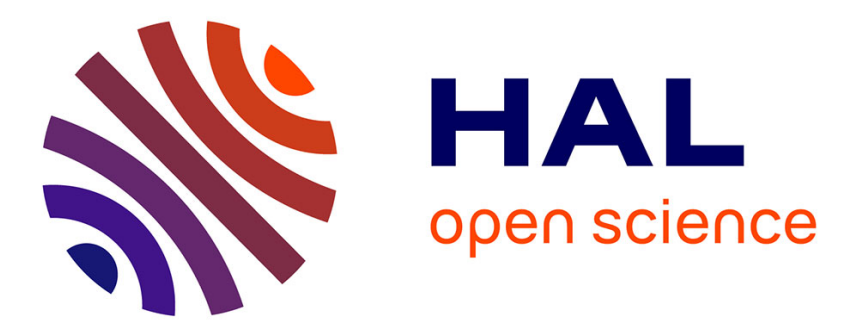

\title{
On-board measurement of emissions from liquefied petroleum gas, gasoline and diesel powered passenger cars in Algeria
}

Saâdane Chikhi, Ménouèr Boughedaoui, Rabah Kerbachi, Robert Joumard

\section{- To cite this version:}

Saâdane Chikhi, Ménouèr Boughedaoui, Rabah Kerbachi, Robert Joumard. On-board measurement of emissions from liquefied petroleum gas, gasoline and diesel powered passenger cars in Algeria. American Journal of Environmental Sciences, 2014, 26, pp.1651-1659. 10.1016/j.jes.2014.06.005 . hal-01250461

\section{HAL Id: hal-01250461 \\ https://hal.science/hal-01250461}

Submitted on 4 Jan 2016

HAL is a multi-disciplinary open access archive for the deposit and dissemination of scientific research documents, whether they are published or not. The documents may come from teaching and research institutions in France or abroad, or from public or private research centers.
L'archive ouverte pluridisciplinaire HAL, est destinée au dépôt et à la diffusion de documents scientifiques de niveau recherche, publiés ou non, émanant des établissements d'enseignement et de recherche français ou étrangers, des laboratoires publics ou privés. 


\title{
On-board measurement of emissions from liquefied petroleum gas, gasoline and diesel powered passenger cars in Algeria
}

\author{
Saâdane Chikhi ${ }^{1,2}$, Ménouèr Boughedaoui ${ }^{1,2,{ }^{*}}$, Rabah Kerbachi ${ }^{2}$, Robert Joumard ${ }^{3}$
}

1. Department of Industrial Chemistry, Faculty of Technology, University of Blida 1, Route de Soumaa, Blida 09000, Algeria. Email: boughedaoui@wissal.dz

2. Environmental Science and Technology Laboratory, National Polytechnic School of Algiers, Algiers 16200, Algeria

3. Transport and Environment Laboratory, Ifsttar, Bron, France

Received 29 October 2013

Revised 25 February 2014

Accepted 19 March 2014

\begin{abstract}
On-board measurements of unit emissions of $\mathrm{CO}, \mathrm{HC}, \mathrm{NO} x$ and $\mathrm{CO}_{2}$ were conducted on 17 private cars powered by different types of fuels including gasoline, dual gasoline-LPG, gasoline, and diesel. The tests performed revealed the effect of LPG injection technology on unit emissions and made it possible to compare the measured emissions to the European Artemis emission model. A sequential multipoint injection LPG kit with no catalyst installed was found to be the most efficient pollutant reduction device for all of the pollutants, with the exception of the NOx. Specific test results for a sub-group of LPG vehicles revealed that LPG-fueled engines with no catalyst cannot compete with catalyzed gasoline and diesel engines. Vehicle age does not appear to be a determining parameter with regard to vehicle pollutant emissions. A fuel switch to LPG offers many advantages as far as pollutant emissions are concerned, due to LPG's intrinsic characteristics. However, these advantages are being rapidly offset by the strong development of both gasoline and diesel engine technologies and catalyst converters. The LPG's performance on a chassis dynamometer under real driving conditions was better than expected. The enforcement of pollutant emission standards in developing countries is an important step towards introducing clean technology and reducing vehicle emissions.
\end{abstract}

\section{Keywords}

Unit emission, Pollutant, Vehicle, On-board measurement, LPG, Gasoline, Diesel 


\section{Introduction}

Thanks to its chemical composition, such as the $\mathrm{H} / \mathrm{C}$ ratio, and to its physicochemical properties, such as calorific capacity (Díaz et al., 2000; Lim et al., 2006), Liquefied Petroleum Gas (LPG) is often considered as a clean alternative fuel to liquid ones, and hence widely used in many countries (Johnson, 2003; Karamangil, 2007). In 2010, the LPG vehicle fleet in the world was estimated at roughly 17 million (WLPGA, 2012), and roughly 0.3 million vehicles have been converted to LPG in Algeria (Boughedaoui et al., 2007). The environmental benefits of LPG have been widely described in scientific articles based on either engine bench or chassis dynamometer emission measurements (Bayraktar and Durgun, 2005; Li et al., 2007; Lai et al., 2009). However, very few on-road measurements of LPG-powered passenger cars have been performed in real driving conditions to assess the environmental performance of LPG fuel in comparison with gasoline and diesel (Lau et al., 2011; Oprešnik et al., 2012).

Initially, chassis dynamometer measurements were designed to test vehicle emissions in view of certification, using a standardized driving cycle. However, standardized driving cycles are not representative of real traffic conditions (André and Rapone, 2009). Alternative techniques to perform on-road measurements of emissions were developed, widely tested and compared with the standard method (Franco et al., 2013). Pelkmans and Debal (2006) conducted measurements on the NEDC standard European cycle in real traffic in two European cities. The emissions measured in real traffic were higher than on the standard driving cycle by at least $60 \%$ and $30 \%$ for diesel and gasoline vehicles, respectively, for almost all pollutants. Nitrogen oxide (NOx) emissions in real traffic were found to be 2 to 4 times higher than emissions measured on the NEDC (Pelkmans and Debal, 2006; Rubino et al., 2007; Daham et al., 2009; Weiss et al., 2011;). Strong acceleration is not considered in the NEDC, making it unrepresentative of real traffic conditions (Weiss et al., 2012). Acceleration, among other driving and environmental conditions, contributes to increase the emission of all pollutants versus emissions measured with NEDC. Finally, it has been shown (Daham et al., 2009; Weiss et al., 2011; Franco et al., 2013) that carbon dioxide $\left(\mathrm{CO}_{2}\right)$ emissions measured using a chassis dynamometer were underestimated by $10 \%$ to $50 \%$ in comparison with real emissions measured with a PEMS (Portable Emission Measurement System) for different vehicles with emission standards from Euro 1 to Euro 4.

It has been noted that emissions are significantly underestimated by chassis dynamometer measurements compared with on-board techniques, which increases the uncertainty of pollutant emission estimation. This calls into question the representativeness of chassis dynamometer measurements with respect to real emissions. On the other hand, real kinematics are still difficult to reproduce on a test bench taking into account all environmental parameters. 
On-board measurement of emissions from liquefied petroleum gas, gasoline and diesel powered passenger cars in Algeria

Only a few measurements with LPG-powered vehicles have been performed on-board to evaluate pollutant emissions under real driving conditions. A vehicle fuel switch from gasoline to LPG was found to decrease $\mathrm{CO}_{2}$ emissions measured on a chassis dynamometer by $14 \%$ (Ristovski, 2005; Yang, 2007), and carbon monoxide (CO) and total hydrocarbons (THC) by $71 \%$ and $89 \%$, respectively. Using the remote sensing technique, Ning and Chan (2007) were able to measure and compare pollutant emissions for LPG, gasoline and diesel powered vehicles. The CO and THC emissions from LPG-powered vehicles were lower than those from gasoline and higher than those from diesel.

Recently, Lau et al. (2011) used PEMS to compare emissions from LPG-powered vehicles on the road and on a chassis dynamometer. The results from the on-road measurements showed higher levels of $\mathrm{CO}$ and THC emissions.

Researchers tend to consider the emissions of vehicles in real traffic as more representative for environmental study purposes. They can enhance road traffic emission inventory control, air quality modeling and air pollution abatement strategies for road transportation (Franco et al., 2013). The abovementioned measurement discrepancies call into question the standard method, whose results are not representative of real emissions under real driving conditions. Therefore, and for more realistic measurement, the purpose of this paper is to explore the environmental efficiency of LPG powered vehicles measured with an on-board system called mini-CVS (Boughedaoui et al., 2008) in real traffic conditions on 17 vehicles equipped with different conversion kits and injection technologies. Such measurements reflect the emissions from used vehicles that take into account real vehicle usage conditions, with a comparison with emissions from gasoline and diesel powered vehicles.

\section{Experiment}

\subsection{Method}

The methodology is based on sampling gaseous pollutants along the route with a mini-CVS. This technique was developed by the Warren Spring Laboratory (UK), then tested and validated by INRETS (France) and used by several research teams (Potter, 1987; Van Ruymbeke, 1993; Boughedaoui, 2008). The mini-CVS sampling system is a reduced and simplified version of the CVS system. It is installed on board the test vehicle and connected to the exhaust pipe (Fig. 1 and 2). The exhaust gas emitted by the vehicle passes through a tapered nozzle attached to the exhaust pipe. The nozzle is composed of 112 parallel tubes assumed to deliver equal flows. Only gases coming from one tube are diluted with ambient air in the dilution chamber and then collected in 
Tedlar bags. The bags are forwarded to the laboratory immediately after each circuit for analysis of the $\mathrm{CO}$, THC, $\mathrm{NO} x$ and $\mathrm{CO}_{2}$ composition. Emission of particles is not measured by this system and is not considered in this study.

\subsection{Analytical instrumentation}

The $\mathrm{CO}$ and $\mathrm{CO}_{2}$ analysis was performed using infrared radiation absorption, with a CosmaEnvironnement SA Crystal 300 device. The NOx was analyzed by chemiluminescence using a Cosma-Environnement SA Topaz 3010 mono-chamber device. The THCs were determined by flame ionization detection (FID) with a Cosma-Environnement SA Graphite 750 device. All devices were calibrated daily with standard gases (purity 99.5\%) supplied by Air Liquide company. The mass of pollutants emitted during each test was converted into an emission factor, taking into account the distance travelled, the temperature, the atmospheric pressure and the humidity of the sampled gas.

\subsection{Vehicles}

The 17 vehicles were randomly selected and borrowed from private owners for the entire testing period. All of the vehicles were owned by individuals from different social and professional categories, and were used for both professional and personal purposes. The vehicles included 6 gasoline-powered, 4 diesel and 7 dual gasoline/LPG vehicles, whose characteristics are shown in Table 1. The subgroup of LPG vehicles was composed of 4 vehicles equipped with a multipoint injection kit and 3 vehicles with sequential multipoint fuel injection (Table 3). These vehicles were assumed to be representative of the Algerian passenger car fleet in 2011 in terms of brand, engine size and age. The tested LPG vehicles included vehicles with and without catalytic converters and with three types of injection systems: simple, multipoint, and sequential multipoint injection.

All 7 dual-fueled vehicles were of the same brand and model, with the exception of one, but they had different ages and mileages. This LPG sub-group allowed better comparison among vehicles by eliminating the variability factor between models and brands. Tests were performed on the vehicles without any prior maintenance.

The characteristics of fuels used in Algeria are the following: the sulfur content in Diesel is 500 ppm, the octane index is 96 for gasoline and 95 for unleaded gasoline, and the cetane index is 51 for diesel. The LPG composition is $96 \%$ propane during hot periods and decreases to $80 \%$ propane in cold periods. Díaz (2000) determined that a mixture with 70\% propane appears to be optimal, since it reduces $\mathrm{CO}$ and $\mathrm{NO} x$ emissions, yet it increases THC emissions. 
On-board measurement of emissions from liquefied petroleum gas, gasoline and diesel powered passenger cars in Algeria

\subsection{Circuit selection}

The road circuits were selected on the basis of kinematic measurements using a chase vehicle within the traffic (Boughedaoui et al., 2008). Ultimately, 7 circuits of 3 types were defined as follows: 3 urban circuits (dense, congested, and fluid) with respective lengths of 2.7, 3.1 and 2.4 $\mathrm{km}, 2$ suburban circuits each $4.2 \mathrm{~km}$ long, and 2 motorway circuits 7.9 and $11.0 \mathrm{~km}$ long (characteristics indicated in Table 2). These 7 circuits are located in Blida in the suburbs of Algiers, the capital city of Algeria. All the test routes used have low gradients of around $0.5 \%$.

\section{5 Emission measurements}

A total of 298 tests were conducted during the period between April and September 2011 (Table 3). Each vehicle was tested at least 3 and up to 6 times on every type of circuit depending on the traffic and environmental conditions. The tests were performed with a hot engine start to avoid the high quantity of pollutants generated by a cold start.

During the test campaign, the vehicle speed was recorded with a Doppler speedometer and a GPS. The ambient temperature ranged between $23^{\circ} \mathrm{C}$ and $36^{\circ} \mathrm{C}$ and the humidity varied from $27 \%$ to $71 \%$. The tests were conducted between 7 am and 8 pm daily during weekdays and on weekends including all types of traffic and roads (urban, suburban, motorway) except the case of no traffic. All vehicles were driven by a single driver to avoid any possible variability associated with driving style that could be significant, as indicated by Holmen and Niemeier (1998). The driver was instructed to drive normally in the traffic flow and to reproduce the average driving traffic conditions as closely as possible.

The data was processed to derive unit emissions in grams of pollutant per km for each test. The results are comparable, since they were recorded on the same circuit and in the same traffic conditions. The THC is expressed in $\mathrm{CH}_{4}$ equivalent and the $\mathrm{NO} x$ in $\mathrm{NO}_{2}$ equivalent. The emissions from the 3 fuels (gasoline, diesel and LPG) were assessed according to the average vehicle speed and classified according to 10 speed classes, each class having the same weight in the recorded speed distribution. Calculations were subsequently performed to derive emission factors for 4 gaseous pollutants $\left(\mathrm{CO}, \mathrm{CO}_{2}, \mathrm{THC}, \mathrm{NO} x\right)$ from the 3 fuels (gasoline, diesel, LPG).

\section{Results and discussion}

Table 4 groups the average emissions for all tests and fuels. The emissions from the vehicles using multipoint injection LPG without a catalyst are higher than those from the non-catalyzed gasolinepowered vehicles. The vehicles fitted with a multipoint sequential injection kit can comply with the Euro 3 standard and compete with the catalyzed gasoline-powered vehicles. Only the multipoint 
injection LPG vehicles equipped with catalysts could achieve the emission performance of the catalyzed diesel vehicle for the four gaseous pollutants measured.

In the case of LPG, the conversion technology used is critical to reduce the levels of pollutant emissions. The emissions from the different LPG systems show that the sequential system is the most efficient as far as pollutant emissions are concerned, with very low levels of $\mathrm{CO}, \mathrm{CO}_{2}$ and THC, but not of NOx.

\subsection{Emissions from gasoline and diesel}

The unit emissions as a function of the average speed are depicted in Figs. 3-6 for a comparison of the different vehicle technologies and fuels.

Non-catalyzed gasoline-powered vehicles emitted high levels of CO, THC and NOx, even for the more recent vehicles less than one year old. Such vehicles are still sold in the market of many developing countries where emission standards are totally lacking or just beginning with Euro 0 to Euro 3 but hardly implemented or controlled. The CO emissions from the non-catalyzed gasoline vehicles ranged from $27 \mathrm{~g} / \mathrm{km}$ at the average speed of $10 \mathrm{~km} / \mathrm{hr}$ to $7 \mathrm{~g} / \mathrm{km}$ at $90 \mathrm{~km} / \mathrm{hr}$. The $\mathrm{CO}_{2}$ varied from 164 to $113 \mathrm{~g} / \mathrm{km}$, the THC from 3.5 to $0.8 \mathrm{~g} / \mathrm{km}$, and the NOx from 1.4 to $1.5 \mathrm{~g} / \mathrm{km}$, for the same speed range. On average, such emission levels of CO, THC and NOx are compliant with pre-Euro standards regardless of the age of the non-catalyzed vehicle considered, up to the most recent vehicle less than one year old.

Catalyzed vehicles are supposed to be fueled with unleaded gasoline, available on the domestic market. However, shortages of unleaded fuel occur periodically, forcing drivers to use leaded gasoline. Catalytic converters are then rarely replaced or maintained due to either high cost or the lack of local technical competence. This is an interesting situation to consider when comparing the impact of different fuels on pollutant emissions in the atmosphere.

The results shown in Table 4 indicate that the dual-fueled vehicles not equipped with catalytic converters emitted high levels of $\mathrm{CO}_{2}$ when tested with gasoline, indicating excessive fuel consumption. This was observed for all the converted vehicles equipped with a basic injection system, which is optimized for LPG fuel when there is only one electronic calculator unit (ECU). It is not the case for the vehicles equipped with a multipoint injection system with two injection controllers (ECU) leading to double optimization regardless of the fuel used (Karamangil, 2007; Li et al., 2010; Gumus, 2011; Gumus and Ugurlu, 2011; Masi, 2012).

For catalyzed gasoline-powered vehicles (between 1 and 5 years old), the CO emissions ranged from $2.5 \mathrm{~g} / \mathrm{km}$ at $10 \mathrm{~km} / \mathrm{hr}$ to $0.3 \mathrm{~g} / \mathrm{km}$ at $90 \mathrm{~km} / \mathrm{hr}$. The $\mathrm{CO}_{2}$ varied from 370 to $163 \mathrm{~g} / \mathrm{km}$, the THC from 0.35 to $0.05 \mathrm{~g} / \mathrm{km}$, and the NOx from 0.06 to $0.22 \mathrm{~g} / \mathrm{km}$, for the same speeds respectively. In this case, these vehicles meet the Euro 1 standard for CO, Euro 2 for NOx and Euro 3 for THC. 
On-board measurement of emissions from liquefied petroleum gas, gasoline and diesel powered passenger cars in Algeria

The emissions from the diesel-powered vehicles equipped with catalytic converters (less than 3 years old) range from $1.9 \mathrm{~g} / \mathrm{km}$ at $10 \mathrm{~km} / \mathrm{hr}$ to $0.3 \mathrm{~g} / \mathrm{km}$ at $90 \mathrm{~km} / \mathrm{hr}$ for CO, from 0.20 to $0.03 \mathrm{~g} / \mathrm{km}$ for THC, and from 1.07 to $0.35 \mathrm{~g} / \mathrm{km}$ for NOx for the same speeds respectively. These vehicles comply with Euro 2 for $\mathrm{CO}$ and Euro 3 for THC and NOx.

Comparable results were obtained by $\mathrm{Hu}$ et al. (2012) with PEMS on-board measurements on 16 catalyzed diesel taxis in Hong Kong. The authors confirmed the efficiency of diesel compared to gasoline-powered vehicles of the same vehicle category. It is worth recalling that the literature reports that diesel engine technology is less polluting compared to that of gasoline as far as $\mathrm{CO}$, $\mathrm{NO} x$, THC and $\mathrm{CO}_{2}$ are concerned. Non-catalyzed gasoline-powered vehicles are the most polluting and their conversion to LPG has been admitted as an alternative for pollution abatement.

\subsection{Emissions from LPG}

In this section, the results of the tests conducted on the LPG-powered vehicles are explored and compared with those obtained for the gasoline and diesel vehicles. The specific issues of NOx, THC and $\mathrm{CO}_{2}$ emissions from LPG fuel are further discussed.

The CO emissions from the non-catalyzed vehicles converted to LPG with multipoint injection ranged from $40 \mathrm{~g} / \mathrm{km}$ at $10 \mathrm{~km} / \mathrm{hr}$ to $5 \mathrm{~g} / \mathrm{km}$ at $90 \mathrm{~km} / \mathrm{hr}$. The THC ranged from 2.5 to $0.6 \mathrm{~g} / \mathrm{km}$ and the NOx from 1.5 to $2.5 \mathrm{~g} / \mathrm{km}$, for the same speeds.

However, the emissions from the same vehicle types converted to LPG with sequential injection were much lower than those from the multipoint injection technology, as illustrated in Figs. 3, 5 and 6 for the CO and THC emissions. They ranged from $1.1 \mathrm{~g} / \mathrm{km}$ at $10 \mathrm{~km} / \mathrm{hr}$ to $1.8 \mathrm{~g} / \mathrm{km}$ at $90 \mathrm{~km} / \mathrm{hr}$ for CO. The THC and NOx emissions ranged from 1.8 to $0.4 \mathrm{~g} / \mathrm{km}$ and from 1.4 to $2.2 \mathrm{~g} / \mathrm{km}$ respectively, for the same speeds.

The emissions observed for the vehicles equipped with a catalyst converter and a sequential LPG injection system were much lower than those from the other two vehicle categories. The $\mathrm{CO}$ emissions varied from $1.25 \mathrm{~g} / \mathrm{km}$ at $10 \mathrm{~km} / \mathrm{h}$ to $0.4 \mathrm{~g} / \mathrm{km}$ at $90 \mathrm{~km} / \mathrm{hr}$. The THC varied from 0.88 to $0.06 \mathrm{~g} / \mathrm{km}$ and the NOx from 0.26 to $0.53 \mathrm{~g} / \mathrm{km}$, for the same speeds.

However, the non-catalyzed vehicles equipped with a sequential multipoint injection kit were significantly less polluting when using LPG than using gasoline (Figs. 1 and 2). Therefore, the technology used in LPG conversion kits has a significant impact on emissions. Multipoint sequential injection maintains engine performance at a level equivalent to gasoline and drastically reduces pollutant emissions. Such results are in accordance with the literature (Gumus, 2011; Gumus and Ugurlu, 2011; Masi, 2012). LPG sequential injection has an undeniable environmental benefit compared to LPG simple injection, even in the case of non-catalyzed vehicles. 


\subsubsection{NOx emissions}

The NOx emissions from the non-catalyzed LPG vehicles for both conversion technologies (sequential and injection) were the highest, ranging from 1.67 to $2.7 \mathrm{~g} / \mathrm{km}$ (Fig. 6).

The average of the maximum accelerations recorded among all the tests on different routes amounts to $1.88 \pm 0.43 \mathrm{~m} / \mathrm{sec}^{2}$ even for low speeds, with a maximum of $2.53 \mathrm{~m} / \mathrm{sec}^{2}$. Strong acceleration is known to generate high levels of NOx (Adam et al., 2011). In real traffic, strong acceleration can increase the formation of NOx, even for catalyzed vehicles, taking into account the deterioration of the three way catalyst (TWC) over time in old vehicles. This could explain why the NOx emissions in the urban or extra urban areas were higher than those measured in Europe, given the strong acceleration measured (André et al., 2006). $2 \mathrm{~g} / \mathrm{km}$ of NOx were thus emitted by both vehicles without a catalyst, whether LPG or gasoline-fueled. For similar vehicles equipped with a catalyst, the emissions decreased to $0.4 \mathrm{~g} / \mathrm{km}$ for the sequential LPG and gasoline engines. Thus, diesel engines still emit relatively high levels of NOx reaching up to $0.6 \mathrm{~g} / \mathrm{km}$ even when equipped with a catalyst. The NOx emissions from LPG remain a crucial issue, as confirmed in the literature (Yang et al., 2007; Adam et al., 2011; Lau et al., 2011, Huang et al., 2013). This is mainly due to the high temperature combustion of LPG $\left(900-1000^{\circ} \mathrm{C}\right)$ versus that of gasoline $\left(500-800^{\circ} \mathrm{C}\right) . \mathrm{LPG}$ vehicles emit more NOx than gasoline engines in catalyzed and non-catalyzed vehicles due to LPG's gas thermodynamic properties compared with gasoline. The air/fuel ratio for LPG is generally 15.5 (depending on LPG composition), a ratio higher than that of gasoline (14.7), leading to excess oxygen emission that limits the effectiveness of the three-way catalyst to reduce NOx (Yang et al., 2007).

Emission measurements performed on a chassis dynamometer with standard cycles such as NEDC or FTP 75 (Daham et al., 2009; Oprešnik et al., 2012; Kousoulidou et al., 2013) have often not included strong acceleration, which overshadows the high NOx emissions measured in real traffic, and consequently have systematically underestimated NOx.

\subsubsection{Excess THC emission}

All dual gasoline-LPG injection vehicles start up in the gasoline mode, even if LPG is selected as the fuel and even if the engine is already warm. The automatic switch to the LPG mode takes place after a certain lapse of time depending on engine temperature, since LPG's ignition temperature $\left(500^{\circ} \mathrm{C}\right)$ is higher than that of gasoline $\left(250^{\circ} \mathrm{C}\right)$ (Yang et al., 2007; Adam et al., 2011). For this reason, specific tests were undertaken to explore the effect on THC emissions of an engine start with gasoline.

Several tests at idling were performed for LPG powered vehicles with a hot engine, to exclude the cold start effect. Samples of exhaust gas were collected for 5 minutes for both of the following 
operations: 1) starting the engine with gasoline and switching automatically to the LPG mode, and 2) starting directly with LPG. When starting with LPG, the THC emission is $10 \%$ to $3 \%$ lower, depending on the vehicle type. Therefore, the excess THC emission of LPG vehicles is partially due to the gasoline engine start, even with a hot engine. This is particularly the case since the cold start phase is critical for pollutant emissions (Weilenmann et al., 2009).

\subsection{3. $\mathrm{CO}_{2}$ emissions}

The $\mathrm{CO}_{2}$ emissions from the non-catalyzed vehicles (Fig. 7) were higher for the sequential injection LPG than for the multipoint injection LPG and the gasoline. This is mainly due to better LPG combustion in the engine and a higher consumption of gaseous fuel (resulting in lower CO and THC emissions with the sequential injection). The air/fuel ratio is better managed by the sequential injection than the multipoint injection, making combustion more efficient.

For catalyzed vehicles, those running on diesel still remain the lowest $\mathrm{CO}_{2}$ emitters, with 162 $\mathrm{g} / \mathrm{km}$ compared to $163 \mathrm{~g} / \mathrm{km}$ emitted by sequential LPG and $209 \mathrm{~g} / \mathrm{km}$ by gasoline. The $\mathrm{CO}_{2}$ emission difference among the 3 fuels varies from 10 to $60 \mathrm{~g} / \mathrm{km}$ depending on the average driving speed.

For both the LPG and diesel fuels, on-board measurements gave similar $\mathrm{CO}_{2}$ emissions for vehicles with or without catalysts for both LPG injection kit systems.

Earlier studies on a chassis dynamometer (Díaz et al., 2000; Ristovski, 2005; Yang, 2007) reported lower $\mathrm{CO}_{2}$ emissions for LPG-based vehicles compared to gasoline-based ones, a fact attributed to the high hydrogen/carbon ratio.

\subsection{Emission standards}

Jung et al. (2011) compared emission factors against average vehicle speed by model and year, reflecting the role of regulations on using improved vehicle emission abatement technology. On the other hand, the lack of emission standards is common to many developing countries (Almasri et al., 2011; Hu et al., 2012). Thus, vehicles are either imported or manufactured without any pollutant emission standards. In Algeria, an emission standard equivalent to Euro 3 does exist but is not enforced, and there is no certification scheme or pollution emission standard inspection scheme. In this case, the only way to assess the vehicle emission standard is to compare the measured emissions with emissions from similar vehicles whose standard is known, such as those in the European Artemis emission database and model (André et al., 2006). Such a comparison was performed by Chan (2004) between his real-life on-road emission measurements in Hong Kong and calculated values from a UK database. Using the characteristics (brand, model, age, fuel type, power, mileage) of the 17 vehicles that we tested (Table 1), each vehicle emission level was 
compared to emissions of equivalent vehicles in the European Artemis database to determine the corresponding Euro standard, qualified as a pseudo Euro standard (Joumard, 2007; Boughedaoui, 2008). Accordingly, the vehicles were categorized in three classes of pseudo Euro standards: 10 vehicles as pseudo Euro 0, 2 vehicles as pseudo Euro 1, and 5 vehicles as pseudo Euro 2.

The non-catalyzed vehicle fitted with a simple LPG injection system hardly met the Euro 1 standard, whereas the catalyzed one met Euro 2. Vehicles equipped with a sequential injection system could comply with the Euro 3 standard in the absence of a catalytic converter (Fig. 4), and even reach Euro 4 when equipped with a catalytic converter. Emissions from the sequential injection LPG vehicles were $0.05,0.27$ and $0.43 \mathrm{~g} / \mathrm{km}$ for CO, THC, and NOx, respectively, which is close to those found by Lau (2011) for a Euro 3 equivalent vehicle. This would give some insight regarding the high performance of the LPG sequential injection technology that can easily meet Euro 3 or Euro 4 standards.

This classification shows that among all the tested vehicles marketed in Algeria in the years 2010 and 2011, many of them are close to Euro 0 standards, corresponding to vehicles marketed prior to 1993 in Europe. This delay in standard compliance is observed in many countries where emission standards are not enforced for new vehicles (Hu et al., 2012). The general belief that vehicles meet the standards of the manufacturing country is unrealistic, since carmakers export vehicles in accordance with the import country regulations. Therefore, renewing a vehicle fleet without considering the emission standard they must meet does not systematically contribute to air pollution abatement.

\subsection{Vehicle maintenance}

The $\mathrm{CO} / \mathrm{CO}_{2}$ and $\mathrm{THC} / \mathrm{CO}_{2}$ ratios express the proportion (in percentage) of unburned gases and are suitable indicators to assess engine maintenance (Pierson, 1996; Chiang, 2008). Due to vehicle aging and the low level of vehicle maintenance, the TWC deteriorates over time, resulting in higher THC, CO and NOx emissions. Table 5 summarizes the values of such ratios for our vehicles. The $\mathrm{CO} / \mathrm{CO}_{2}$ and $\mathrm{THC} / \mathrm{CO}_{2}$ ratios for all the non-catalyzed vehicles are respectively $5.3 \%$ and $0.67 \%$, and are higher than those of their counterpart vehicles in the Artemis database. The level of maintenance is closer to that of Euro 0 vehicles operated in Europe according to the Artemis database.

The same low level of maintenance has been observed for light duty vehicles using similar onboard measurements (Boughedaoui, 2008). Even in the case of relatively new vehicles, many studies have revealed that a low level of maintenance is the cause of high pollutant emissions, leading to the loss of LPG's environmental advantage. 
On-board measurement of emissions from liquefied petroleum gas, gasoline and diesel powered passenger cars in Algeria

\section{Conclusions}

Our project was designed to study the emissions of private, in-use cars using gasoline, diesel and LPG fuels. An on-board system was used to measure the emissions of these vehicles during real use. The pollutant emission levels were studied with respect to fuel and engine technology.

Under real driving conditions, the LPG performance appears to be lower than expected based on the chassis dynamometer. The NOx emissions are higher or comparable depending on the type of conversion kit and the catalyst converter if installed.

There is evidence that many new cars are as polluting as older ones. This indicates that vehicles imported by developing countries do not systematically meet the latest standards in force in the country of origin. The enforcement of pollutant emission standards by the importing country is the only way to introduce cleaner technology and reduce vehicle emissions.

Measurements on LPG vehicles helped to distinguish between the emission levels by using the LPG conversion kit technology, and to highlight the importance of adjusting the conversion kit as well as of engine maintenance. LPG can compete with liquid fuels as an alternative fuel only if third and fourth generation LPG conversion kits are used, corresponding respectively to multipoint and sequential injection.

A switch to LPG fuel offers many advantages regarding pollutant emissions due to its intrinsic characteristics. Yet due to insufficient LPG optimization and maintenance, these advantages are being rapidly offset by the significant progress of both gasoline and diesel engine technologies and catalysts.

Further work on the real emissions of unregulated pollutants from different fuels will contribute to better assess air pollution due to engine fuel combustion.

\section{References}

(World Liquefied Petroleum Gas Association), WLPGA, 2012. Autogas incentive policies. World Liquefied Petroleum Gas Association, Neuilly-sur-Seine, France. http://www.worldlpgas.com/uploads/Autogas_Incentives_policies_2012.pdf (accessed Sept 09, 2013)

Adam, T.W., Astorga, C., Clairotte, M., Duane, M., Elsasser, M., Krasenbrink, A., 2011. Chemical analysis and ozone formation potential of exhaust from dual-fuel (liquefied petroleum gas/gasoline) light duty vehicles. Atmos. Environ. 45(17), 2842-2848.

Almasri, R., Muneer, T., Cullinane, K., 2011. The effect of transport on air quality in urban areas of Syria. Energy Policy 39(6), 3605-3611.

André, M., Rapone, M., Adra, N., Pollak, I., Keller, M., McCrae, I., 2006. Traffic characteristics for the estimation of pollutant emissions from road transport-Artemis deliverable 10. Inrets report, Bron, France, LTE 0606, 89 p. http://www.inrets.fr/ur/lte/publiautresactions/fichesresultats/ficheartemis/road3/modelling33/Artemis_de110_traffic_char_LTE0606.pdf (Accessed Sept. 12, 2013)

André, M., Rapone, M., 2009. Analysis and modelling of the pollutant emissions from European cars regarding the driving characteristics and test cycles. Atmos. Environ. 43(5), 986-995. 
Bayraktar, H., Durgun, O., 2005. Investigating the effects of LPG on spark ignition engine combustion and performance. Energy Conver. Manag. 46(13-14), 2317-2333.

Boughedaoui, M., 2007. Etude des émissions polluantes issues du trafic routier en Algérie [Study of pollutant emissions from road vehicular traffic in Algeria. Doctoral Thesis, Ecole Nationale Polytechnique d'Alger, Algiers, 27 Dec. 2007.

Boughedaoui, M., Kerbachi, R., Joumard, R., 2008. On-board emission measurement of high-loaded lightduty vehicles in Algeria. J. Air Waste Manag. Associat. 58(1), 45-54.

Chan T., L., Ning, Z., Leung, C.W., Cheung, C.S., Hung, W.T., Dong, G., 2004. On-road remote sensing of petrol vehicle emissions measurement and emission factors estimation in Hong Kong. Atmos. Environ. 38 (14), 2055-2066.

Chiang, H.L., Tsai, J.H., Yao, Y.C., Ho, W.Y., 2008. Deterioration of gasoline vehicle emissions and effectiveness of tune-up for high-polluted vehicles. Transpor. Res. Part D: Trans. Environ. 13(1), 47-53.

Daham, B., Li, H., Andrews, G.E., Ropkins, K., Tate, J.E., Bell, M.C., 2009. Comparison of Real World Emissions in Urban Driving for Euro 1-4 Vehicles Using a PEMS. SAE Technical Paper, No. 2009-010941.

Díaz, L., Schifter, I., López-Salinas, E., Gamas, E., Rodriguez, R., Avalos, S., 2000. Optimizing automotive LPG blend for Mexico City. Fuel 79(1), 79-88.

Franco, V., Kousoulidou, M., Muntean, M., Ntziachristos, L., Hausberger, S., Dilara, P., 2013. Road vehicle emission factors development: A review. Atmos. Environ. 70, 84-97.

Gumus, M., 2011. Effects of volumetric efficiency on the performance and emissions characteristics of a dual fueled (gasoline and LPG) spark ignition engine. Fuel Proc. Technol. 92(10), 1862-1867.

Gumus, M., Ugurlu, A., 2011. Application of phase change materials to pre-heating of evaporator and pressure regulator of a gaseous sequential injection system. Appl. Energy 88(12), 4803-4810.

Holmen, B.A., Niemeier, D.A., 1998. Characterizing the effects of driver variability on real-world vehicle emissions. Transpor. Res. Part D: Trans. Environ. 3(2), 117-128.

Hu, J.N., Wu, Y., Wang, Z.S., Li, Z.H., Zhou, Y., Wang, H.T. et al., 2012. Real-world fuel efficiency and exhaust emissions of light-duty diesel vehicles and their correlation with road conditions. J. Environ. Sci. 24(5), 865-874.

Huang, C., Lou, D.M., Hu, Z.Y., Feng, Q., Chen, Y.R., 2013. A PEMS study of the emissions of gaseous pollutants and ultrafine particles from gasoline- and diesel- fueled vehicles, Atmos. Environ. 77, 703-710.

Johnson, E., 2003. LPG: A secure, cleaner transport fuel? A policy recommendation for Europe. Energy Policy 31(15), 1573-1577.

Joumard, R., J.M., Rapone, M., Zallinger, M., Kljun, N., André, M. et al., 2007. Emission factor modelling and database for light vehicles. Artemis deliverable 3, INRETS report LTE 0523, Bron, France, 237 pp. http://www.inrets.fr/ur/lte/publi-

autresactions/fichesresultats/ficheartemis/road3/database32/Artemis_deliverable_3_LTE0523_adobe7.pdf (accessed Aug. 30, 2013)

Jung, S., Lee, M., Kim, J., Lyu, Y., Park, J., 2011. Speed-dependent emission of air pollutants from gasolinepowered passenger cars. Environ. Technol. 32(11), 1173-1181.

Karamangil, M.I., 2007. Development of the auto gas and LPG-powered vehicle sector in Turkey: A statistical case study of the sector for Bursa. Energy Policy 35(1), 640-649.

Kousoulidou, M., Fontaras, G., Ntziachristos, L., Bonnel, P., Samaras, Z., Dilara, P., 2013. Use of portable emissions measurement system (PEMS) for the development and validation of passenger car emission factors. Atmos. Environ. 64, 329-338.

Lai, C.H., Chang, C.C., Wang, C.H., Shao, M., Zhang, Y., Wang, J.L., 2009. Emissions of liquefied petroleum gas (LPG) from motor vehicles. Atmos. Environ. 43(7), 1456-1463.

Lau, J., Hung, W.T., Cheung, C.S., 2011. On-board gaseous emissions of LPG taxis and estimation of taxi fleet emissions. Sci. Total Environ. 409(24), 5292-5300.

Li, G., Li, L.G., Liu, Z., Li, Z.M., Qiu, D.P., 2007. Real time NO emissions measurement during cold start in 


\section{On-board measurement of emissions from liquefied petroleum gas, gasoline and diesel powered}

passenger cars in Algeria

LPG SI engine. Energy Conver. Manag. 48(9), 2508-2516.

Li, X.Q., Yang, L.K., Pang, M., Liang, X.J., 2010. Effect of LPG Injection Methods on Engine Performance. Adv. Mater. Res. 97-101, 2279-2282.

Lim, M.K.C.H., Ayoko, G.A., Morawska, L., Ristovski, Z.D., Jayaratne, E.R., Kokot, S., 2006. A comparative study of the elemental composition of the exhaust emissions of cars powered by liquefied petroleum gas and unleaded gasoline. Atmos. Environ. 40(17), 3111-3122.

Masi, M., 2012. Experimental analysis on a spark ignition gasoline petrol engine fuelled with LPG (liquefied petroleum gas). Energy 41(1), 252-260.

Ning, Z., Chan, T.L., 2007. On-road remote sensing of liquefied petroleum gas (LPG) vehicle emissions measurement and emission factors estimation. Atmos. Environ. 41(39), 9099-9110.

Oprešnik, S.R., Seljak, T., Bizjan, F., Katrašnik, T., 2012. Exhaust emissions and fuel consumption of a triple-fuel spark-ignition engine powered passenger car. Transpor. Res. Part D: Trans. Environ.17(3), 2121-227.

Pelkmans, L., Debal, P., 2006. Comparison of on-road emissions with emissions measured on chassis dynamometer test cycles. Transpor. Res. Part D: Trans. Environ. 11(4), 233-241.

Pierson, W.R., Gertler, A.W., Robinson, N.F., Sagebiel, J.C., Zielinska, B., Bishop, G.A., 1996. Real-world automotive emissions: Summary of Studies studies in the Fort McHenry and tuscarora mountain tunnels. Atmos. Environ. 30(12), 2233-2256.

Potter, C.J., 1987. The on-the-road measurement of emissions from gasoline and diesel engined vehicles. Pollut. Atmos. 29(spec. issue.), 57-69.

Ristovski, Z.D., Jayaratne, E.R., Morawska, L., Ayoko, G.A., Lim, M., 2005. Particle and carbon dioxide emissions from passenger vehicles operating on unleaded gasoline and LPG fuel. Sci. Total Environ. 345(1-3), 93-98.

Rubino, L., Bonnel, P., Hummel, R., Krasenbrink, A., Manfredi, U., 2007. Mobile measurement of pollutant emissions and fuel consumption of road vehicles in real-world driving situations using portable emission measurement systems (PEMS). Final report, Eur. Commission, Ispra, Italy, 61 pp.

http://ec.europa.eu/clima/policies/transport/vehicles/docs/2007_pems_jrc_413194_en.pdf (accessed Sept. 09, 2013)

Van Ruymbeke, C., Guitton, J.P., Vidon, R., Pruvost, C., 1993. Test d'une méthode alternative de mesures des émissions de polluants des voitures particulières. Sci. Total Environ. 134(1-3), 197-209.

Weilenmann, M., Favez, J.Y., Alvarez, R., 2009. Cold-start emissions of modern passenger cars at different low ambient temperatures and their evolution over vehicle legislation categories. Atmos. Environ. 43(15), 2419-2429.

Weiss, M., Bonnel, P., Hummel, R., Provenza, A., Manfredi, U., 2011. On-road emissions of light-duty vehicles in Europe. Environ. Sci. Technol. 45(19), 8575-8581.

Weiss, M., Bonnel, P., Kühlwein, J., Provenza, A., Lambrecht, U., 2012. Will Euro 6 reduce the NOx emissions of new diesel cars? - Insights from on-road tests with Portable Emissions Measurement Systems (PEMS). Atmos. Environ. 62, 657-665.

Yang, H.H., Chien, S.M., Cheng, M.T., Peng, C.Y., 2007. Comparative study of regulated and unregulated air pollutant emissions before and after conversion of automobiles from gasoline power to liquefied petroleum gas/gasoline dual-fuel retrofits. Environ. Sci. Technol. 41(24), 8471-8476. 
Table 1 Characteristics of the tested vehicles

\begin{tabular}{|c|c|c|c|c|c|c|c|}
\hline Brand & Model & Fuel & Year & $\begin{array}{l}\text { Engine } \\
\text { capacity }\left(\mathrm{cm}^{3}\right)\end{array}$ & $\begin{array}{l}\text { Power } \\
(\mathrm{kW})\end{array}$ & Catalyst & $\begin{array}{l}\text { Mileage } \\
(1000 \mathrm{~km})\end{array}$ \\
\hline $\begin{array}{l}\text { Volkswage } \\
\text { n }\end{array}$ & Golf & Gasoline & 1989 & 1300 & 40 & $\mathrm{w} / \mathrm{o}$ & na \\
\hline Toyota & Echo & Gasoline & 2004 & 1497 & 79 & w/o & 82 \\
\hline Dacia & Logan & Gasoline & 2006 & 1400 & 55 & with & 82 \\
\hline Toyota & $\begin{array}{l}\text { Yaris } \\
\text { Sedan }\end{array}$ & Gasoline & 2008 & 1298 & 78 & w/o & 110 \\
\hline Renault & Symbol & $\begin{array}{l}\text { unleaded } \\
\text { gasoline }\end{array}$ & 2009 & 1390 & 55 & with & 5 \\
\hline Toyota & $\begin{array}{l}\text { Yaris } \\
\text { Sedan }\end{array}$ & Gasoline & 2011 & 1298 & 78 & w/o & 9 \\
\hline Renault & Symbol & $\begin{array}{l}\text { unleaded } \\
\text { gasoline- } \\
\text { LPG }\end{array}$ & 2011 & 1390 & 55 & with & 10 \\
\hline Chevrolet & Aveo & $\begin{array}{l}\text { Gasoline- } \\
\text { LPG }\end{array}$ & 2004 & 1498 & 63 & w/o & 179 \\
\hline Chevrolet & Aveo & $\begin{array}{l}\text { Gasoline- } \\
\text { LPG }\end{array}$ & 2006 & 1498 & 63 & w/o & 145 \\
\hline Chevrolet & Aveo & $\begin{array}{l}\text { Gasoline- } \\
\text { LPG }\end{array}$ & 2007 & 1498 & 63 & w/o & 61 \\
\hline Chevrolet & Aveo & $\begin{array}{l}\text { Gasoline- } \\
\text { LPG }\end{array}$ & 2008 & 1498 & 85 & $\mathrm{w} / \mathrm{o}$ & 28 \\
\hline Chevrolet & Optra & $\begin{array}{l}\text { Gasoline } \\
\text { LPG }\end{array}$ & 2010 & 1598 & 79 & w/o & 30 \\
\hline Chevrolet & Aveo & $\begin{array}{l}\text { Gasoline- } \\
\text { LPG }\end{array}$ & 2010 & 1498 & 63 & $\mathrm{w} / \mathrm{o}$ & 67 \\
\hline Renault & Clio & Diesel & 1998 & 1870 & 48 & w/o & 405 \\
\hline Renault & Scenic & Diesel & 2002 & 1870 & 77 & with & 25 \\
\hline Toyota & Corolla & Diesel & 2004 & 1995 & 85 & with & 177 \\
\hline Ford & Fiesta & Diesel & 2010 & 1398 & 50 & with & 29 \\
\hline
\end{tabular}

w/o: without, na: not available.

Table 2 Average kinematics parameters of different circuit types

\begin{tabular}{llllllll}
\hline Circuit types & $\begin{array}{l}\text { Circuit } \\
\text { length } \\
(\mathrm{km})\end{array}$ & $\begin{array}{l}\text { Average } \\
\text { speed } \\
(\mathrm{km} / \mathrm{hr})\end{array}$ & $\begin{array}{l}\text { Average } \\
\text { maximum } \\
\text { speed } \\
(\mathrm{km} / \mathrm{hr})\end{array}$ & $\begin{array}{l}\text { Average } \\
\text { positive } \\
\text { acceleratio } \\
\mathrm{n}\left(\mathrm{m}_{\left.\mathrm{sec}^{2}\right)}\right.\end{array}$ & $\begin{array}{l}\text { Average } \\
\text { trip } \\
\text { duration } \\
(\mathrm{sec})\end{array}$ & $\begin{array}{l}\text { Average } \\
\text { stop } \\
\text { time } \\
(\mathrm{sec})\end{array}$ & $\begin{array}{l}\text { Average } \\
\text { number } \\
\text { of stops }\end{array}$ \\
\hline Urban 1 & 2.7 & 12.58 & 17.48 & $0.33(\max )$ & 773 & 166 & 15 \\
Urban 2 & 3.1 & 12.89 & 21.86 & $0.36(\max )$ & 866 & 156 & 16 \\
Urban 3 & 2.4 & 18.69 & 26.70 & $0.44(\max )$ & 462 & 36 & 5 \\
Suburban 1 & 4.2 & 34.63 & 39.48 & 0.41 & 437 & 62 & 2 \\
Suburban 2 & 4.2 & 52.98 & 60.72 & 0.57 & 285 & 35 & 1 \\
Motorway 1 & 7.9 & 75.14 & 86.18 & 0.09 & 378 & 0 & 0 \\
Motorway 2 & 11 & 89.90 & 107.87 & 0.15 & 440 & 0 & 0 \\
\hline
\end{tabular}


On-board measurement of emissions from liquefied petroleum gas, gasoline and diesel powered passenger cars in Algeria

Table 3 Test distribution by fuel, vehicle and route

\begin{tabular}{|c|c|c|c|c|c|c|}
\hline \multirow{2}{*}{ Vehicle } & \multirow{2}{*}{ Fuel } & \multirow{2}{*}{$\begin{array}{r}\text { Number of } \\
\text { tested } \\
\text { vehicles }\end{array}$} & \multicolumn{4}{|c|}{ Number of tests } \\
\hline & & & Urban & Suburban & Motorway & Total \\
\hline $\begin{array}{r}\text { Single fuel } \\
\text { without } \\
\text { catalyst }\end{array}$ & Gasoline & 4 & 32 & 13 & 15 & 60 \\
\hline Single fuel & Gasoline & 2 & 9 & 5 & 7 & 21 \\
\hline with catalyst & Diesel & 4 & 21 & 11 & 13 & 45 \\
\hline \multirow{3}{*}{$\begin{array}{r}\text { Dual-fuel } \\
\text { without } \\
\text { catalyst }\end{array}$} & Gasoline & 6 & 37 & 19 & 18 & 74 \\
\hline & LPG injection & 4 & 27 & 13 & 12 & 52 \\
\hline & $\begin{array}{r}\text { LPG sequential } \\
\text { injection }\end{array}$ & 2 & 10 & 6 & 6 & 22 \\
\hline \multirow{2}{*}{$\begin{array}{r}\text { Dual-fuel with } \\
\text { catalyst }\end{array}$} & Gasoline & 1 & 6 & 3 & 3 & 12 \\
\hline & $\begin{array}{r}\text { LPG sequential } \\
\text { injection }\end{array}$ & 1 & 6 & 3 & 3 & 12 \\
\hline
\end{tabular}

Table 4 Average emission factors for different fuels and technologies

\begin{tabular}{|c|c|c|c|c|c|c|}
\hline \multirow{2}{*}{\multicolumn{2}{|c|}{ Fuel types }} & \multirow{2}{*}{ Catalyst } & \multicolumn{4}{|c|}{ Emission factor $(\mathrm{g} / \mathrm{km})$} \\
\hline & & & $\mathrm{CO}$ & $\mathrm{THC}$ & NOx & $\mathrm{CO}_{2}$ \\
\hline \multirow{3}{*}{\multicolumn{2}{|c|}{ Gasoline }} & $\mathrm{w} / \mathrm{o}$ & $10.69 \pm 7.07$ & $1.58 \pm 0.96$ & $1.51 \pm 0.26$ & $176.1 \pm 44.6$ \\
\hline & & & & & & \\
\hline & & with & $0.81 \pm 0.69$ & $0.20 \pm 0.18$ & $0.30 \pm 0.15$ & $209.8 \pm 68.1$ \\
\hline \multirow{4}{*}{ Dual-fuel } & Gasoline & $\mathrm{w} / \mathrm{o}$ & $9.01 \pm 5.02$ & $1.27 \pm 0.69$ & $1.88 \pm 0.38$ & $204.9 \pm 73.9$ \\
\hline & $\begin{array}{l}\text { LPG multi } \\
\text { point } \\
\text { injection }\end{array}$ & w/o & $11.81 \pm 10.55$ & $1.11 \pm 0.84$ & $1.60 \pm 0.26$ & $175.2 \pm 62.1$ \\
\hline & $\begin{array}{l}\text { LPG multi } \\
\text { point }\end{array}$ & w/o & $1.20 \pm 0.69$ & $0.84 \pm 0.55$ & $2.11 \pm 0.36$ & $207.7 \pm 61.3$ \\
\hline & $\begin{array}{l}\text { sequential } \\
\text { injection }\end{array}$ & with & $0.51 \pm 0.37$ & $0.20 \pm 0.24$ & $0.44 \pm 0.19$ & $163.2 \pm 57.0$ \\
\hline \multicolumn{2}{|l|}{ Diesel } & with & $0.75 \pm 0.50$ & $0.05 \pm 0.05$ & $0.52 \pm 0.23$ & $162.0 \pm 34.9$ \\
\hline
\end{tabular}


Table 5 Vehicle maintenance indicator compared to the Artemis database

\begin{tabular}{|c|c|c|c|c|c|c|c|}
\hline \multirow{2}{*}{ Fuel type } & \multirow{2}{*}{ Catalyst } & \multirow{2}{*}{ Model year } & \multicolumn{2}{|c|}{ Measurements } & \multicolumn{3}{|c|}{ European Artemis } \\
\hline & & & $\mathrm{CO} / \mathrm{CO}_{2}$ & $\mathrm{HCT} / \mathrm{CO}_{2}$ & Standards & $\mathrm{CO} / \mathrm{CO}_{2}$ & $\mathrm{HCT} / \mathrm{CO}_{2}$ \\
\hline \multirow{2}{*}{$\begin{array}{l}\text { Gasoline } \\
\text { (mono fuel) }\end{array}$} & w/o & 1988- 2011 & $5.67 \pm 2.23$ & $0.85 \pm 0.34$ & $\begin{array}{l}\text { Euro 0 } \\
\text { (gasoline) }\end{array}$ & $9.16 \pm 4.01$ & $\begin{array}{c}1.253 \pm \\
0.610\end{array}$ \\
\hline & with & 2006-2011 & $0.24 \pm 0.13$ & $0.09 \pm 0.07$ & $\begin{array}{l}\text { Euro } 1 \\
\text { (gasoline) }\end{array}$ & $1.04 \pm 0.25$ & $0.084 \pm 0.022$ \\
\hline \multirow{2}{*}{$\begin{array}{l}\text { Gasoline } \\
\text { (dual-fuel) }\end{array}$} & w/o & $2004-2010$ & $4.25 \pm 1.07$ & $0.59 \pm 0.13$ & $\begin{array}{l}\text { Euro } 2 \\
\text { (gasoline) }\end{array}$ & $0.43 \pm 0.10$ & $0.035 \pm 0.011$ \\
\hline & with & 2011 & $0.36 \pm 0.19$ & $0.05 \pm 0.03$ & $\begin{array}{l}\text { Euro } 3 \\
\text { (gasoline) }\end{array}$ & $0.47 \pm 0.29$ & $0.011 \pm 0.004$ \\
\hline $\begin{array}{l}\text { LPG Inj. } \\
\text { (Dual-fuel) }\end{array}$ & w/o & 2004-2010 & $5.94 \pm 3.26$ & $0.58 \pm 0.27$ & $\begin{array}{l}\text { Euro } 4 \\
\text { (gasoline) }\end{array}$ & $0.21 \pm 0.15$ & $0.007 \pm 0.002$ \\
\hline \multirow{2}{*}{$\begin{array}{l}\text { LPG Seq. } \\
\text { Inj. (Dual- } \\
\text { fuel) }\end{array}$} & $\mathrm{w} / \mathrm{o}$ & $2010-2011$ & $0.63 \pm 0.40$ & $0.38 \pm 0.16$ & $\begin{array}{l}\text { Euro 1 } \\
\text { (diesel) }\end{array}$ & $0.21 \pm 0.08$ & $0.021 \pm 0.011$ \\
\hline & with & 2011 & $0.34 \pm 0.16$ & $0.10 \pm 0.06$ & $\begin{array}{l}\text { Euro 2 } \\
\text { (diesel) }\end{array}$ & $0.13 \pm 0.10$ & $0.017 \pm 0.008$ \\
\hline Diesel & with & $1998-2010$ & $0.44 \pm 0.21$ & $0.03 \pm 0.02$ & $\begin{array}{l}\text { Euro 3 } \\
\text { (diesel) }\end{array}$ & $0.04 \pm 0.03$ & $0.009 \pm 0.004$ \\
\hline
\end{tabular}

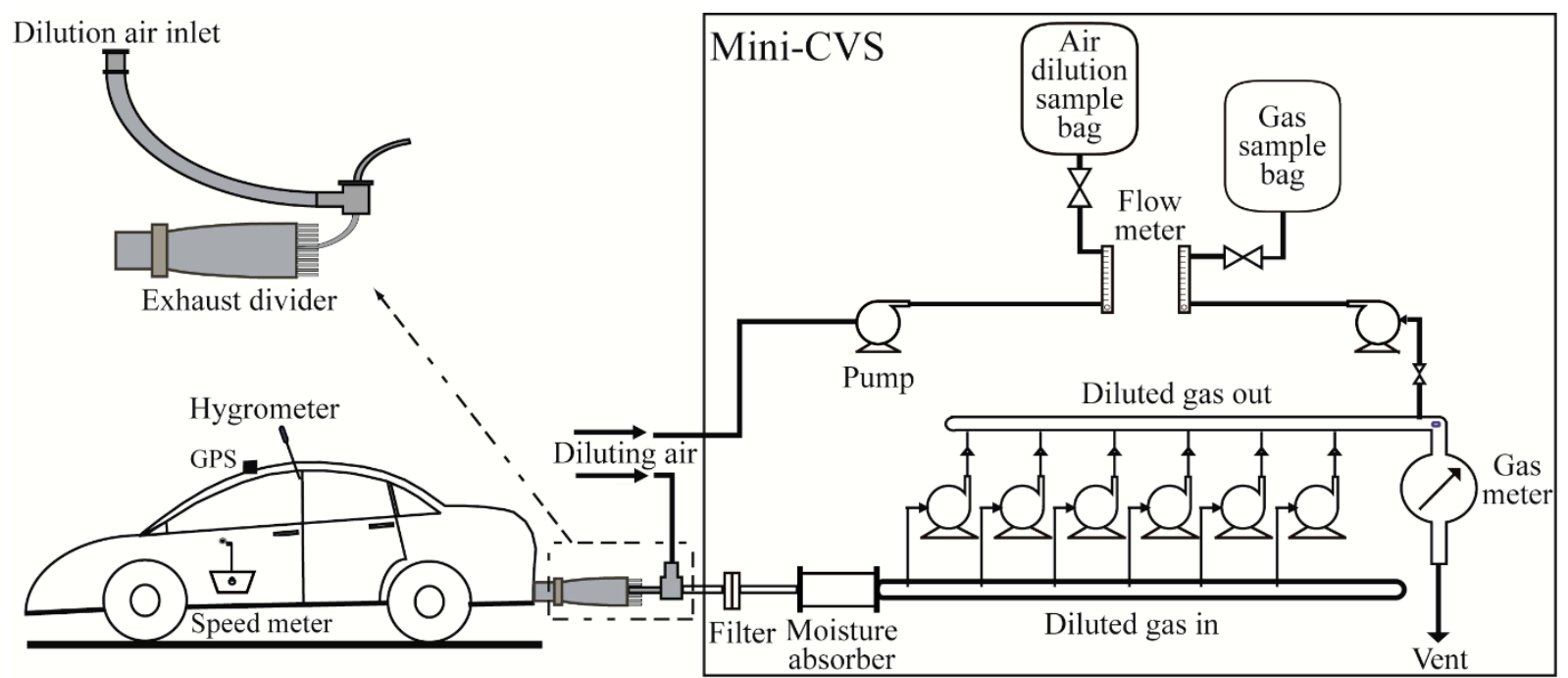

Fig. 1 On-board sampling system. 
On-board measurement of emissions from liquefied petroleum gas, gasoline and diesel powered passenger cars in Algeria
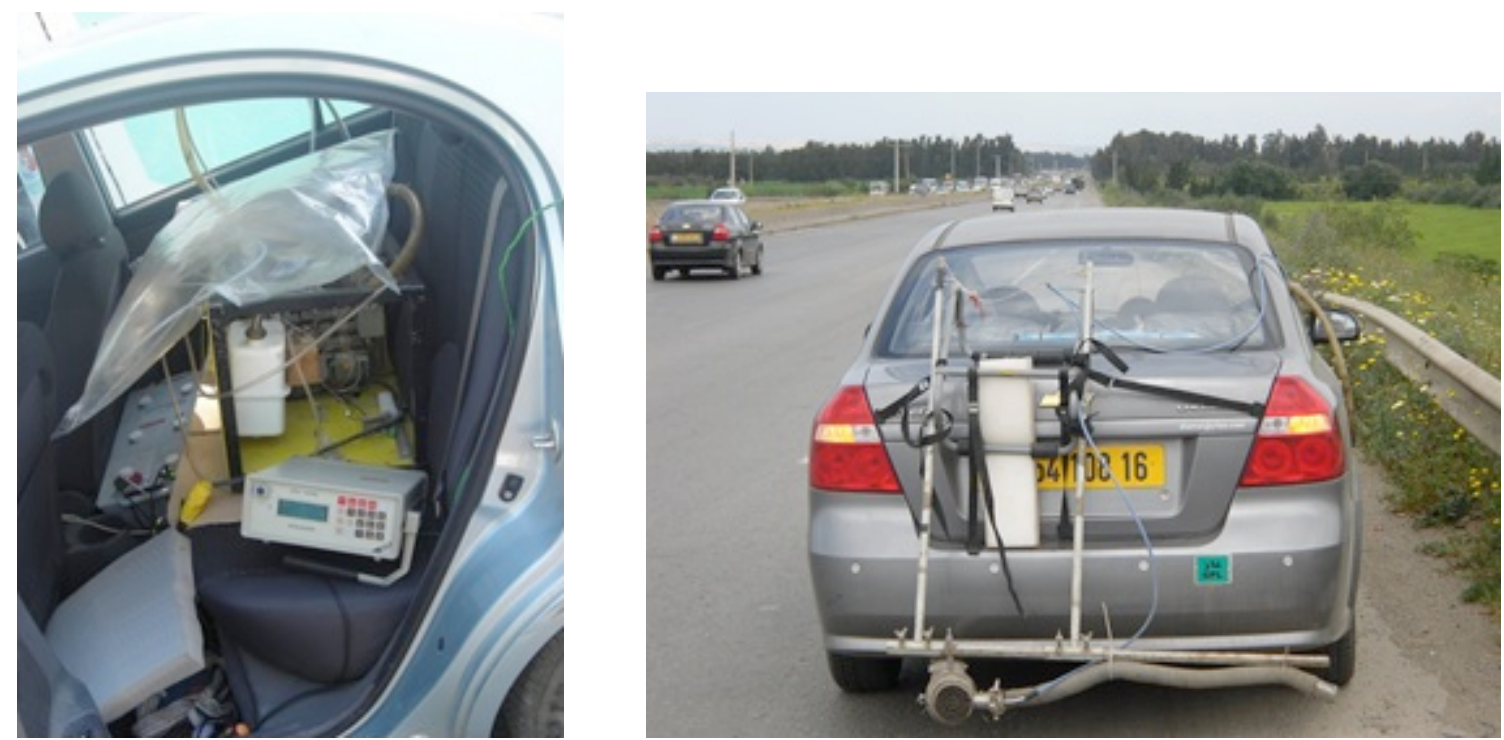

Fig. 2 Instrumented vehicle with the mini-CVS measurement system.

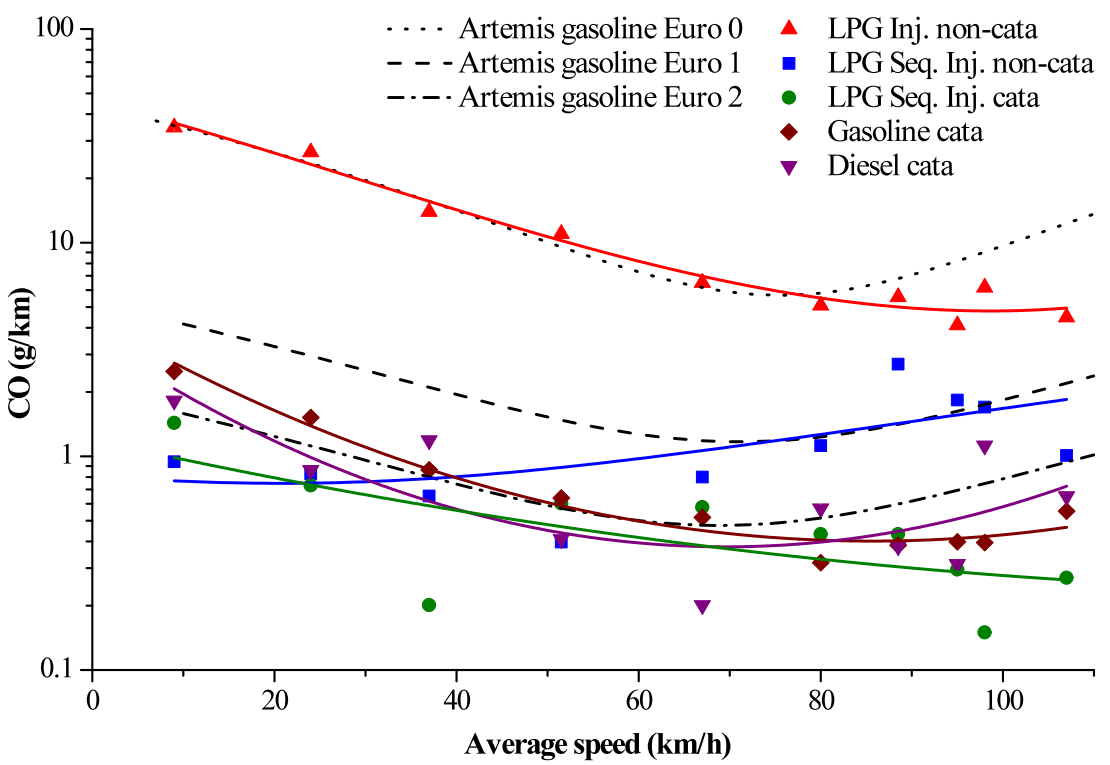

Fig. $3 \mathrm{CO}$ emissions for different fuels and technologies, and comparison with European Artemis model. 


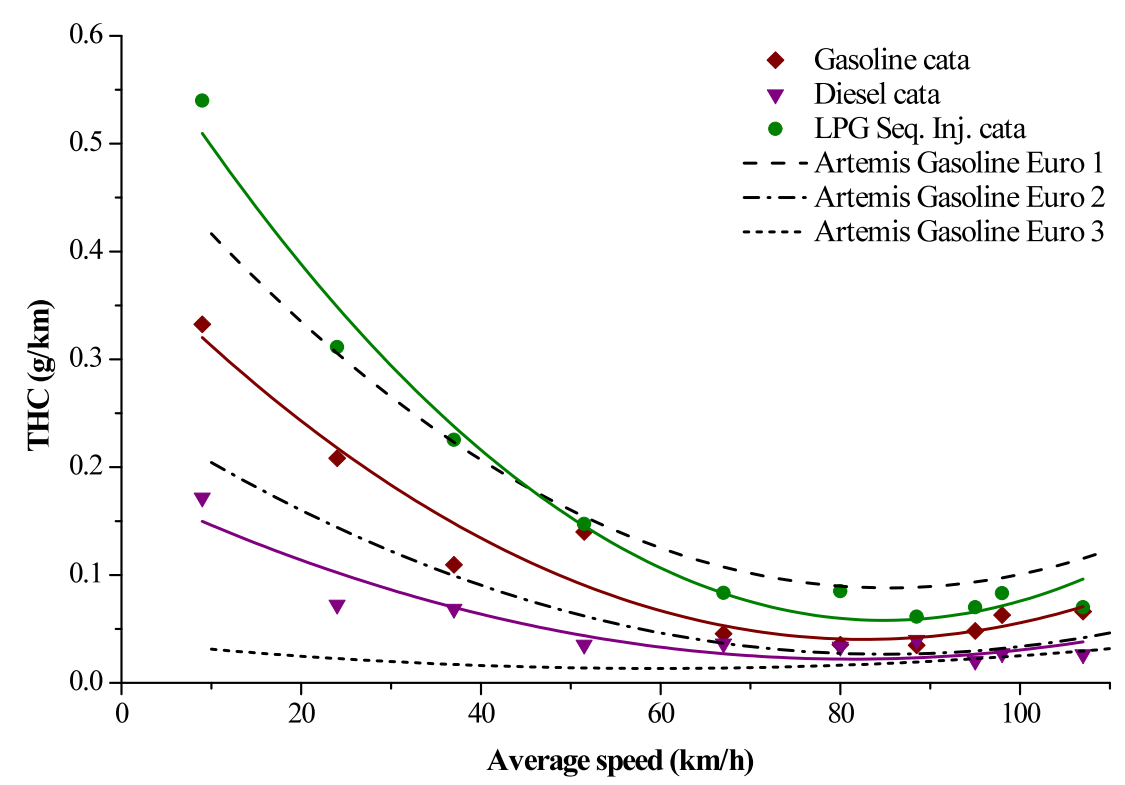

Fig. 4 THC emissions for 3 fuels of catalyzed vehicles and comparison with European Artemis model.

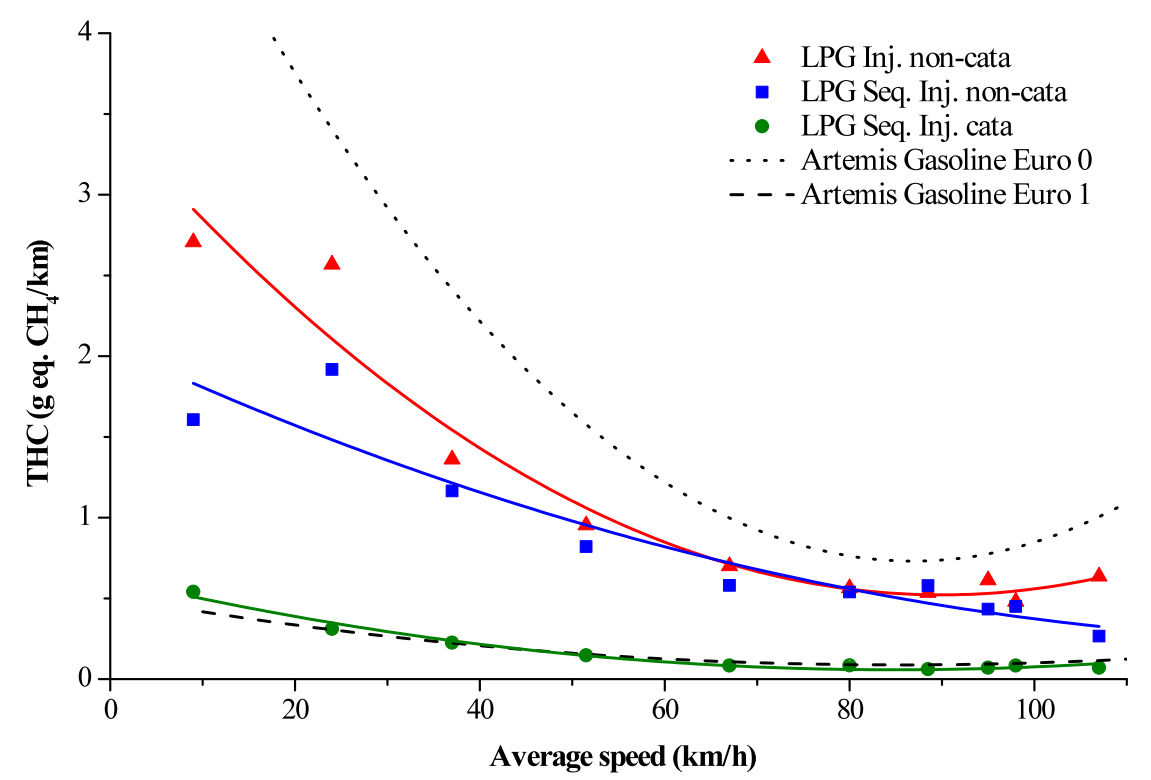

Fig. 5 THC emissions for LPG powered vehicles and comparison with European Artemis model. 
On-board measurement of emissions from liquefied petroleum gas, gasoline and diesel powered passenger cars in Algeria

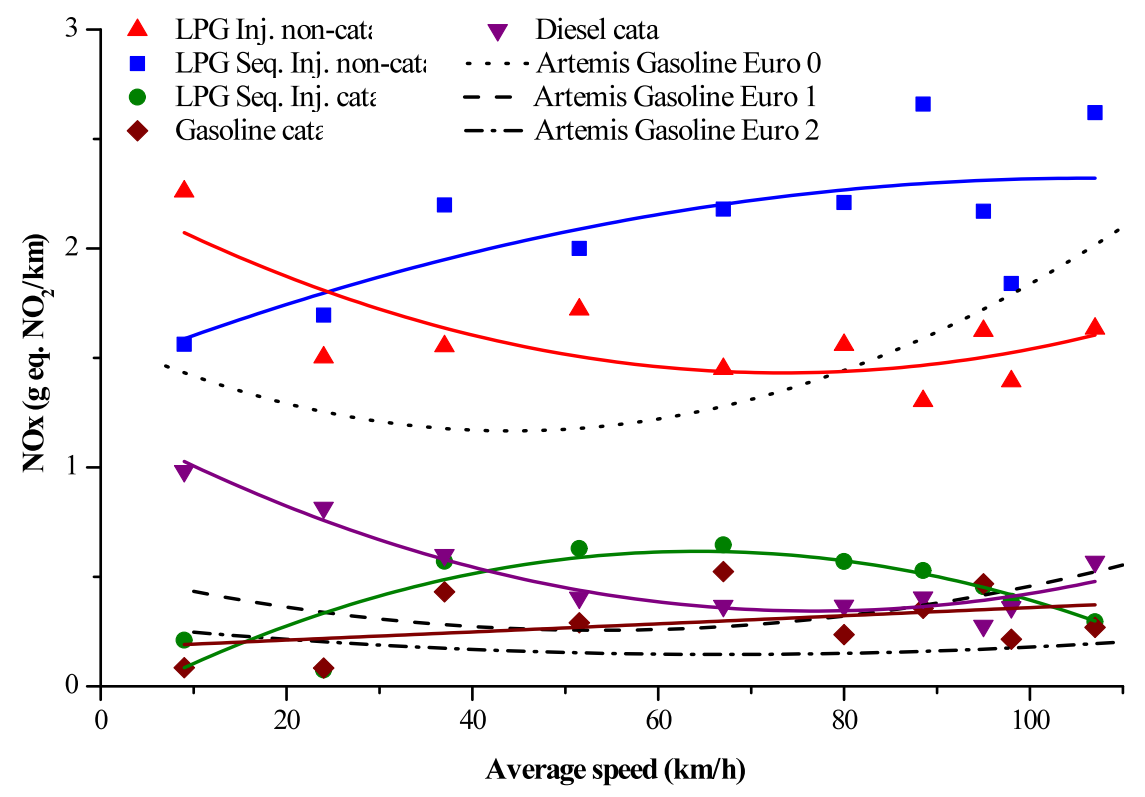

Fig. $6 \mathrm{NO} x$ emission for 3 fuels for all vehicles, and comparison with European Artemis model.

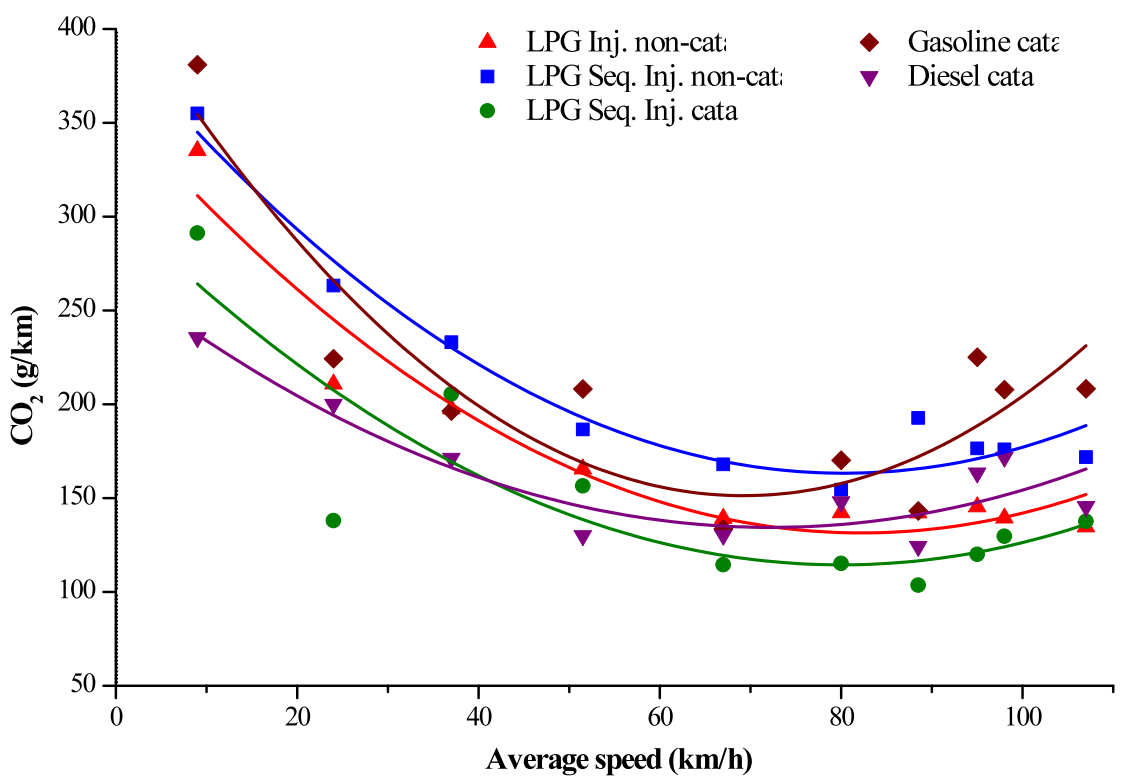

Fig. $7 \mathrm{CO}_{2}$ emissions for the different vehicle categories. 